\title{
Flow analysis of groundwater with seasonal variation of temperature, electric conductivity, and oxygen isotope for heat utilization in Sho River alluvial fan, Toyama, Japan
}

\section{Kaname Iwatake}

University of Toyama: Toyama Daigaku

Akira Ueda ( $\square$ akira@sci.u-toyama.ac.jp )

Toyama Daigaku

\section{Research Article}

Keywords: groundwater, seasonal variation, oxygen isotope, heat utilization, flow mode, alluvial fan

Posted Date: March 30th, 2021

DOI: https://doi.org/10.21203/rs.3.rs-321685/v1

License: @ (i) This work is licensed under a Creative Commons Attribution 4.0 International License. Read Full License 


\section{Abstract}

Seasonal variation of water temperature, electric conductivity, and oxygen isotope composition was determined in the Sho River alluvial fan, western Toyama Prefecture, to examine groundwater heat utilization for indoor climate control. Samples were collected at 31 sites every 2 months for 1 year and at 11 representative sites monthly. The groundwater sources are a mixture of river water and precipitation. The contribution of precipitation to groundwater is generally small along the Sho River but reaches as much as $80 \%$ along the Oyabe River and in the south and west of the alluvial fan. Though the origin of the groundwater differs regionally, water temperature is fixed at about $15^{\circ} \mathrm{C}$ throughout the year in the northern part of the alluvial fan, and open ground source heat pump systems can be used for cooling and heating there.

\section{Introduction}

In Toyama Prefecture, Japan, a large amount (1 million tons/year) of groundwater flows from the mountains ( 3,000 $\mathrm{m}$ in altitude) to the Sea of Japan within $100 \mathrm{~km}$ (Toyama Prefecture, 2006). Most rivers in Toyama Prefecture have the highest hydraulic gradient in Japan. Because the water temperature of shallow groundwater in Toyama is approximately $15^{\circ} \mathrm{C}$ throughout the year (Toyama Prefecture, 2006), groundwater can be used as a heat source for indoor climate control of houses and industry, using the temperature difference between air and groundwater. Geothermal heat pumps (ground source heat-pump systems [GSHP]) effectively use groundwater as a source for indoor climate control and melting snow on roads. In summer, groundwater that is cooler than the atmospheric temperature can be used to cool houses. In contrast, groundwater is warmer than the atmospheric temperature in winter. In this system, the water temperature, quality, and mode of water movement are important parameters for groundwater use. A constant groundwater supply is required for long-term use of a GSHP device. The quality of groundwater is also important to maintain high heat exchange efficiency during operation. Geothermal heat pumps are generally divided into two types: open and closed. In the closed type, a heat exchange facility is installed by drilling a well, and underground heat is recovered by passing heat-containing fluid through a U-shaped pipe. For the open type, groundwater is pumped from the ground and used directly. Therefore, this second type can be used only where there is groundwater. Water quality is changed by the return of groundwater to the ground, and the problem of chemical precipitation (scale) in the heat exchanger must be considered. However, the open type has the advantages of more efficient recovery of geothermal heat and lower initial costs (e.g., Andritsos and Karabelas 2003; Lei et al. 2011; Wang et al. 2012).

There are many studies of water movement in alluvial fans (e.g., Mizutani and Oda, 1983; Li et al., 2008; Hidalgo and Cruz-Sanjulian, 2001; Mizutani et al., 2001; Chkirbene et al., 2009; Yuan et al., 2011; Vanderzalm et al., 2011; Tsuchihara et al., 2011). Recently, several reports have been published on the chemical characteristics of groundwater in Japan for the purpose of using groundwater heat (Takizawa 2011; loka et al. 2013; Iwatake et al. 2013; Yamada and Ueda 2018; Mori et al., 2020; Okano et al., 2020; Matsuura et al., 2021). There also has been research on the environmental influence on water quality and water temperature changes of reinjected groundwater after heat extraction (e.g., Hartog et al. 2013; Saito 
and Komatsu 2014; Park et al 2015; García-Gil et al. 2016; Gjengedal et al. 2019; Pophillat et al. 2020; Pratiwi and Trutnevyte, 2021).

In the vast Sho River alluvial fan, there are two major rivers, the Sho and Oyabe Rivers (Fig. 1), that flow from Nanto City into the Sea of Japan via Takaoka City in the north. There are previous reports on the state of recharge and groundwater flow in the Sho River alluvial fan based on stable isotope and chemical components (Mizutani and Oda, 1983; Kato et al., 1984; Mizutani et al., 1987). Recently, Iwatake et al. (2013) reported a linear relationship between $\delta D$ and $\delta^{18} O$ values for groundwater and river water in the region and posited that groundwater originated as a mixture of Sho and Oyabe River waters and precipitation in varying proportions. The $\delta D$ and $\delta^{18} O$ values for groundwater vary from $-47 \%$ o to $-65 \%$ o and from $-8.1 \%$ o to $-10.6 \%$, respectively. The range of variation in $\delta D$ and $\delta^{18} \mathrm{O}$ values is smaller for the Sho River than for the Oyabe River, and the Sho River originates from higher elevations. Iwatake et al. (2013) also analyzed the chemical composition of groundwater collected in August 2011 and showed that groundwater is enriched in $\mathrm{Ca}^{2+}$ and $\mathrm{HCO}_{3}{ }^{-}$by dissolution of carbonate rocks. They evaluated this area for the applicability of GSHP and the degree of scale creation by chemical components such as iron and calcium carbonate. However, these previous studies discussed single sampling results and did not provide detailed seasonal variations over a year. It has been reported that the flow rate of groundwater in the middle reaches of the Sho River is as fast as 10-13 m/day (Mizutani and Oda, 1983), suggesting that seasonal variation is large in the Sho River alluvial fan.

The aim of this study is to examine annual seasonal variations of groundwater flow patterns in the Sho River alluvial fan and to select suitable areas for open-type GSHP for industrial and domestic use. In the northern Sho River alluvial fan, groundwater has been used for industry, melting snow on roads, and drinking. Excessive extraction of groundwater in the past resulted in land subsidence, causing permanent damage. Such land subsidence has been reported elsewhere, and correlations between groundwater level and changes in surface morphology have also been studied (e.g., Chen et al., 2010). Therefore, the ultimate goal is to apply GSHP, which uses groundwater heat, not only to indoor climate control and winter agricultural production but also to environmental pollution. Samples were taken every month or every two months for a year, and the geochemical characteristics of groundwater in the target area were determined by analyzing oxygen isotope composition. The feasibility of groundwater heat utilization was also examined.

\section{Outline Of The Sho River Alluvial Fan}

The Sho River alluvial fan is located in the western part of Toyama Prefecture and spans the Tonami plain in the central part of the fan (Fig. 1a). Two big rivers, Sho and Oyabe, flow through the fan. Takaoka city is located in the northern part of the fan and Nanto City in the southern part (Fig. 1b). A geologic map of the area is shown in Fig. 1a (AIST, 2015). The study area consists of coarse-grained andesitic breccia derived from the surrounding mountains and hills. There are coarse layer deposits in the upper and central areas of the fan. In addition, two or three clay layers are present at the end of the fan around Takaoka (e.g., Iwatake et al., 2013). Quaternary unconsolidated or semi-consolidated sediments are distributed on the 
alluvial plain and fan. They form aquifers containing abundant groundwater. In Toyama Prefecture, approximately 1 million tons of groundwater per year flow approximately $100 \mathrm{~km}$ from mountain ranges (with altitudes of $3,000 \mathrm{~m}$ ) to the coast. The Sho and Oyabe River basins have rich groundwater resources, and therefore, $70 \%$ of the groundwater in Toyama Prefecture exists in this area (Toyama Prefecture, 2006).

The minimum and maximum air temperatures are $0^{\circ} \mathrm{C}$ in winter and $35^{\circ} \mathrm{C}$ in summer along the Japan Sea in northern Central Japan (Fig. 2; Japan Meteorological Agency, 2020). A large amount of snow falls in winter. Annual precipitation is 3,200 $\mathrm{mm}$ at Shirakawa, where the Sho River originates, and 2,300 $\mathrm{mm}$ in Takaoka area (ocean side) (Toyama Prefecture, 2006). There is a small amount of precipitation (rain) in summer, but more than $80 \mathrm{~mm} /$ day sometimes falls (Fig. 2). The Sho River alluvial fan is surrounded by mountains, and the southern part is in a mountainous region (Fig. 1b). Underground temperatures become nearly constant below depths of approximately $10 \mathrm{~m}$ and are $1^{\circ} \mathrm{C}$ to $2^{\circ} \mathrm{C}$ higher than annual mean air temperature over the land. Underground water temperatures are commonly close to average air temperatures (e.g., Yamamoto, 1992; Bartolino and Niswonger, 1999; Bartolino. 2003; Sekiya, 2003; Hanova and Dowlatabadi, 2007). On the basis of these factors, the groundwater temperature in the study area is estimated to be $14^{\circ} \mathrm{C}$ to $15^{\circ} \mathrm{C}$.

\section{Sample Locality And Analytical Procedures}

The study area and water sampling sites are detailed in Table 1 and Fig. 1b. Since April 2012, groundwater samples have been collected monthly at 11 representative sites, and once every 2 months at another 31 sites for a year (Table 2). River water was sampled 11 times a year in the upper and lower areas of the Sho and Oyabe Rivers (Fig. 1b, Table 3). Within this region, Okakita et al. (2019) measured precipitation at two observation stations (P1 and P2 in Fig. 1b) every month in the same time frame as this study (May 2012 to May 2014), and their data were used in this study. Most groundwater samples were collected from wells. Depths of groundwater wells are up to $100 \mathrm{~m}$, but water levels at the sampling sites were not known, even by the owners. Water sample for oxygen isotope ratio was collected in a $50 \mathrm{~mL}$ plastic bottle, after washing three times with sample water. Because the groundwater and river water samples were colorless and transparent, filtration and acid treatment were not carried out in the field.

Water temperature, $\mathrm{pH}$, electric conductivity (EC), and oxidation-reduction potential (ORP) were measured at the sampling site using a thermometer (YI Chun waterproof digital thermometer), a pH meter (TOA HM31P), an EC meter (TOA CM-31P), and an ORP meter (TOA RM-30P), respectively.

The oxygen isotope $\left(\delta^{18} 0\right)$ composition was determined by a sector mass spectrometer (VG Optima) after pretreatment with $\mathrm{CO}_{2}-\mathrm{H}_{2} \mathrm{O}$ isotope exchange equilibrium (Epsteins and Mayeda, 1953) at $25^{\circ} \mathrm{C}$. The results were reported relative to $\mathrm{V}$-SMOW with an analytical precision of $\pm 0.1 \%$ o.

\section{Results And Discussion}

The results obtained in this study are shown in Tables 2 and 3 and in Figs. 3 through 11, where the sample location numbers correspond to those in Table 1 and Fig. $1 \mathrm{~b}$. 


\subsection{Seasonal variation of river and groundwater temperature}

River water temperatures show seasonal variations, reaching over $30^{\circ} \mathrm{C}$ in summer and dropping to about $5^{\circ} \mathrm{C}$ in winter (Fig. 3a). This change is linked to the air temperature variation, but the water temperature in the Sho River is about $10^{\circ} \mathrm{C}$ lower than that in the Oyabe River in summer. This is judged to be due to the fact that the catchment area of the Sho River is a mountain with a high elevation.

Water temperature variation of 11 representative groundwater samples collected monthly for 1 year are shown in Figs. 3b and 3c. On the basis of water temperature variations, groundwater behavior similar to the rivers, with high temperature in summer and low temperature in winter, was arbitrarily designated as Type 1, and groundwater with little variation throughout the year was designated as Type 2 (Figs. 3b and 3c). Groundwater sites corresponding to Type 1 are sites 4, 8, 10, and 14, with the first three along the Oyabe River and the other on the Sho River (Fig. 1b). The water temperature of Type 2 groundwater fluctuates within the range of $\pm 2^{\circ} \mathrm{C}$ per year (Fig. 3c). The month with maximum water temperature of the Type 1 groundwater varies from region to region. Sample sites 4 and 14 are in August at the same time as river water, sites 8 and 10 is around October (Fig. 3b). The latter two groundwaters are thought to have sprung up several months after they infiltrated into the ground, whether they originated in river water or precipitation. Type 2 groundwater has constant water temperature throughout a year, but the mean value varies in the range of $12-16^{\circ} \mathrm{C}$, with no regional differences (Fig. 3c). The annual average air temperature in Takaoka City is $13.9^{\circ} \mathrm{C}$ (Japan Meteorological Agency, 2020). Underground temperatures are generally constant throughout the year at depths of $10 \mathrm{~m}$ or more, which will generally match the annual average temperature of the area (e.g., Yamamoto, 1992; Bartolino and Niswonger, 1999; Bartolino. 2003; Sekiya, 2003; Hanova and Dowlatabadi, 2007). As a result, groundwater with a residence time of 1 year or more will be close to the average air temperature value in that area. It is therefore possible to infer the residence time of groundwater by comparing groundwater and river water temperatures to air temperature. Water temperature is an important tracer for investigating groundwater flow. Figure 4a illustrates the temperature differences of groundwater and river water across the region between (August 2012) and winter (March 2013). More than one-thirds of the groundwater in the study area plotted far from the line in Fig. 4a, and some groundwater (Nos. 3, 27, and 41) has approached river water values. The sample No. 39 was struck farther away from the other groundwater samples and showed peculiar values of $28^{\circ} \mathrm{C}$ in summer and $15^{\circ} \mathrm{C}$ in winter. This point is located near the coastal area near the Hodatsu Hills. These indicate that residence time is shorter as samples approach the composition of river water. The distributions of groundwater temperatures during summer and winter and the differences between them are shown in Fig. 5. The temperature of river water is shown by the color of the squares. There are no differences in groundwater temperature between summer and winter except for some sites. The water temperature variations are larger at sites $3,39,41$, and 27 than for the other groundwater sites. The former two sites are located along the Hodatsu Hills and sites 27 and 41 are located in the center and southern regions, respectively. In particular, considering that the temperature difference at the No. 3 site is as much as $20.6^{\circ} \mathrm{C}$ (Fig. $5 \mathrm{C}$ ). This indicates that precipitation gushes out as groundwater as soon as it infiltrates underground. In contrast, the residence time of groundwater in the areas with no temperature differences is 
estimated to be more than 1 year. Such groundwater is distributed from the central area to the northern area of the alluvial fan, except for sites 3, 27, and 39.

\subsection{Seasonal variation of groundwater EC}

The EC value of groundwater, regardless of whether it originates from precipitation or river water, is expected to increase as the residence time increases due to the reaction with surrounding rocks after infiltration into the ground. Therefore, EC values are also a good indicator of residence time. There are two precipitation observation sites in the study area, and EC values of precipitation were below $6 \mathrm{mS} / \mathrm{m}$ throughout the year. EC values tend to increase in winter (Okakita et al., 2019), when precipitation mainly comes from air masses originating in mainland China. Winter precipitation is more acidic, and rich in $\mathrm{SO}_{4}{ }^{2-}$ than precipitation in summer (Okakita et al., 2019). The EC value of river water is higher than that of precipitation and also tends to rise slightly in winter (Fig. 6a), reflecting the contribution of precipitation. Precipitation in the study area infiltrates into the ground and becomes $\mathrm{Ca}^{2+}-\mathrm{HCO}_{3}{ }^{-}$type (Iwatake et al., 2013) groundwater by reaction with surrounding rocks before flowing out to the river.

Types 1 and 2 groundwaters had almost constant EC throughout the year (Figs. 6b, 6c, and 4c) with values that were comparable to or higher than river water $(10 \pm 5 \mathrm{mS} / \mathrm{m})$. In particular, the water temperature of the groundwater in type 1 shows seasonal variation, but the $\mathrm{EC}$ value is constant. Figure $7 \mathrm{a}$ shows the distribution of groundwater EC values in the study area. EC values of groundwater along the Sho River and in the southern region are low. In contrast, sites 2 and 39 in the northern region show high values. These two sites are located along the Oyabe River and close to the Hodatsu Hills (Fig. 1b).

\subsection{Seasonal variation of groundwater $\delta^{18} 0$}

At two observation sites in the study area, Okakita et al. (2019) reported $\delta D$ and $\delta^{18} O$ for precipitation every month for 2 years starting in May 2012. The $\delta^{18} \mathrm{O}$ values vary widely throughout a year from $16.0 \%$ o to $-6.2 \%$ with a weighted average of $-9.0 \%$ considering the amount of precipitation. There is a relationship between $\delta D$ and $\delta^{18} O\left(\delta D=8 \delta^{18} O+d\right.$; Craig, 1961 ; Dansgaard, 1964) in precipitation, and it has been reported that $d$ values varied continuously from about $10 \%$ in summer to $30 \%$ in winter with an average of $15.7 \%$ in this region. This $d$ value has been observed intermittently since 1982 and fluctuates in the range of $10.0-26.6 \%$ (Okakita et al., 2019).

The river waters of the Sho and Oyabe Rivers had approximately constant $\delta^{18} O$ values throughout a year, and no significant difference was found between upstream and downstream sampling points of the same river (Fig. 8a). The $\delta^{18} \mathrm{O}$ value for the Sho River was approximately $1 \%$ o lower than that of the Oyabe River. This is a result of the fact that the Sho River originates from precipitation in mountainous areas at high elevations (Mizutani and Oda, 1983; Iwatake et al., 2013). The mean $\delta^{18} 0$ values for the Sho River and Oyabe River are $-10.7 \%$ and $-9.6 \%$, respectively.

The $\delta^{18} \mathrm{O}$ values for groundwater are approximately constant throughout the year, varying between - $11 \%$ and $-8 \%$ with no differences between Types 1 and 2 (Figs. 8b and 8c). Figure $7 \mathrm{~b}$ shows the distribution 
of $\delta^{18} O$ values in August 2012. Groundwater with low $\delta^{18} O$ values is distributed along the Sho River and values rise as distance from the river increases (Fig. 7b). As shown in the legend of Fig. 7b, the $\delta^{18} \mathrm{O}$ values of the Oyabe River are intermediate between those of precipitation falling on the Hodatsu Hill and Sho River water, and the same result is obtained from the $\delta D-\delta{ }^{18} O$ diagram by Iwatake et al (2013). Therefore, it is difficult to determine whether the groundwater around the Oyabe River is formed by seepage water from the Oyabe River water or a mixture of precipitation from the Hodatsu Hill and river water from the Sho River. Figure $7 \mathrm{~b}$ also shows the $\delta^{18} \mathrm{O}$ values (green squares) of the summer river water of the Oyabe River, but the areas of high river water infiltration are not clear. This trend is also observed in the results of the analysis of the geographical distribution of the $\delta^{18} \mathrm{O}$ values of groundwater collected every two months (not shown as a figure). This suggests that the groundwater around the Oyabe River is likely to be formed mainly by a mixture of precipitation and Sho River water, although some areas may be contributed by seepage water from the Oyabe River. Based on these results, we assumed that the groundwater in the Sho River alluvial fan is a mixture of precipitation and Sho River water, and the mixing ratio was examined using the $\delta^{18} \mathrm{O}$ values obtained in this study. The contribution of precipitation to groundwater is shown in Eq. 1.

Percent contribution $(\%)=\left(\delta^{18} O_{\text {groundwater }}-\delta^{18} O_{\text {river water }}\right) /\left(\delta^{18} O_{\text {precipitation }}-\delta^{18} O_{\text {river water }}\right) \times 100(1)$

The $\delta^{18} \mathrm{O}$ values for precipitation and river water were set as $-9.0 \%$ and $-10.7 \%$, respectively, which are the annual weighted averages (Okakita et al., 2019) at observation site P1 (Fig. 1b) and for Sho River water in this study, respectively (Table 3). The percentages of precipitation in groundwater during four seasons (April, August, and December 2012 and March 2013) are shown in Fig. 9. The contribution of precipitation to groundwater varies widely from region to region, with more than $80 \%$ in the southern consistent with the results of Mori et al. (2020) and eastern areas of the study area and in the western part of the Oyabe River. In contrast, it ranges from $10-60 \%$ in other regions, and it was $20 \%$ or less in the region near the Sho River where river water infiltrates. The percentage of precipitation in groundwater varies with the season, and especially in southern regions, the contribution is higher in winter. Iwatake et al. (2013) collected groundwater at almost the same site as our sampling in August 2011 and determined $\delta^{18} 0$ values. Okakita et al. (2019) used the weighted average values of precipitation and the average values of river water to show variations in the contribution ratio of precipitation (the inset of Fig. 9b shows an illustration from Okakita et al. (2019) with some additions and modifications). In this study, the average measured value was set as the river water value, and it agreed with the value used by Okakita et al (2019). Compared with the results of this study, the percentage of precipitation in groundwater in 2011 was as high as $70 \%$ or more in the western part of the study area and changed over the course of a year. This suggests that even if the water temperature is almost constant throughout the year, the percentage of precipitation in Sho River water changes.

\subsection{Groundwater flow in the Sho River alluvial fan and heat utilization}


To use GSHP safely, water movement and groundwater quality are important parameters. In particular, the use of open-type GSHP is recommended in areas with high groundwater flow, such as the Sho River alluvial fan, as it is inexpensive. In this case, groundwater must be abundant, have a stable temperature, and contain few scale components that could precipitate in a heat exchanger or piping. Groundwater EC values range from 8.8 to $37.1 \mathrm{mS} / \mathrm{m}$ with the exception of site 39 (75 to $114 \mathrm{mS} / \mathrm{m}$ ) (Table 2) which is almost the same as or slightly higher than river water $(7.7$ and $37.8 \mathrm{mS} / \mathrm{m}$; Table 3$)$.

Iwatake et al. (2013) and Mori et al. (2021) examined the saturation index of scale components from groundwater in the Sho River alluvial fan and pointed out that Fe compounds tend to precipitate in groundwater with high Fe concentration. In this study, considering these results, the areas circled in blue in Fig. 10 were judged to be recommended areas for the use of open-type GSHPs because the water temperature fluctuations were within $\pm 2^{\circ} \mathrm{C}$ throughout the year and problems such as scale did not occur in these areas. The three areas shown in green were judged to use of open-type GSHP because the groundwater level is expected to be stable, although the temperature difference between water temperature and air temperature is not large due to the large water temperature fluctuation. In the southern region and the western region near Hodatsu Hill, the use of closed-type GSHP was more promising because there were scale problems and large fluctuation of groundwater throughout a year.

\section{Conclusions}

The Sho River alluvial fan in Toyama Prefecture is saturated with groundwater, and the use of inexpensive open-type GSHP is proposed. In a previous pilot study, the chemical and isotope composition of groundwater and river water were determined at a single site, and the hydrology was discussed. In this study, samples were collected at 11 sites every month and at 31 sites every 2 months to examine seasonal variations of chemical and oxygen isotope composition. It was found that groundwater mainly formed by mixing of Sho River water and precipitation, but it varied seasonally. More detailed sites as suitable sites for open-type GSHP were selected. These sites are areas where the annual water temperature is almost constant, but the source water varies from region to region.

\section{Declarations}

\section{Acknowledgments}

The authors wish to thank members of the Geochemical Laboratory of the University of Toyama for their kind advice and cooperation during this study, especially J. Zhang, M. Kusakabe, K. Horikawa, and N. Okakita. The authors would like to thank Enago (www.enago.jp) for the English language review.

\section{References}

AIST, 2015. 1/200,000 Japan Seamless Geological Survey, edited by the Geological Survey of Japan, National Institute of Advanced Industrial Science and Technology. 
Andritsos, N., Karabelas, A.J., 2003. Calcium carbonate scaling in a plate heat exchanger in the presence of particles, Journal of Heat and Mass Transfer, 46, 4613-4627.

Bartolino, J.R. 2003. The Rio Grande-Competing demands for a desert river. In Heat as a Tool for Studying the Movement of Ground Water Near Streams, ed. D.A. Stonestrom and J. Constantz, 8-16. USGS Circular 1260. Reston, Virginia: USGS.

Bartolino, J.R., and R.G. Niswonger. 1999. Numerical simulation of vertical ground-water flux of the Rio Grande from ground-water temperature profiles, central New Mexico. Water Resources Investigation Report 99-4212. Albu-querque, New Mexico: USGS.

Chen, C., Wang, C., Hsu, Y., Yu, S., and Kuo, L., 2010. Correlation between groundwater level and altitude variations in land subsidence area of the Choshuichi Alluvial Fan, Taiwan. Engineer. Geol., 115, 122-131.

Chkirbene, A., Tsujimura, M., Charef, A., Tanaka, T., 2009. Hydro-geochemical evolution of groundwater in an alluvial aquifer: Case of Kurokawa aquifer, Tochigi prefecture, Japan, Desalination, 246, 485-495.

Craig, H., 1961. Standard for reporting concentrations of deuterium and oxygen-18 in natural waters. Science 133 (3467):1833-1834. doi.10.1126/science.133.3467.1833

Dansgaard, W., 1964. Stable isotopes in precipitation. Tellus 16(4):436-438.Epsteins, S. and Mayeda, T., 1953. Variation of the 180/160 ratio in natural waters. Geochim. Cosmochim. Acta, 4, 213-224.

Epstein, S. and Mayeda, T., 1953. Variation of the 180/160 ratio in natural waters. Geochim. Cosmochim. Act 4, 213-224.

García-Gil, A., Epting, J., Garrido, E., Vázquez-Suñé, E., Lázaro, J.M., Navarro, A.S., Huggenberger, H., Calvo, M.A.M., 2016. A city scale study on the effects of intensive groundwater heat pump systems on heavy metal contents in groundwater. Sci. Total Environ. 572, 1047-1058.

Gjengedal, S., Stenvik, L.A., Storli, P-T.S., Ramstad, R.K., Hilmo, B.O., Frengstad, B.S., 2019. Design of groundwater heat pump systems. Principles, tools, and strategies for controlling gas and precipitation problems. Energies 12, 3657.

Hanova, J., Dowlatabadi, H., 2007. Strategic GHG reduction through the use of ground source heat pump technology, Environ. Res. Lett., 2, https://doi.org/10.1088/1748-9326/2/4/044001.

Hartog, N., Drijver, B., Dinkla, I. and Bonte, M., 2013. Field assessment of the impacts of aquifer thermal energy storage (ATES) systems on chemical and microbial groundwater composition. European Geotherm. Congress $1-8$.

Hidalgo, M. C., Cruz-Sanjulian, C., 2001. Groundwater composition, hydrochemical evolution and mass transfer in a regional detrital aquifer (Baza basin, southern Spain), Applied Geochemistry, 16, 745-758. 
loka, S., Muraoka, H., Marui, A. and Ikawa, R., 2013. Evaluation of groundwater quality for an open-system geothermal heat pump system in the Pacific coast area of Aomori Prefecture. J. Geotherm. Soc. Japan 35, 111-117. (in Japanese with English abstract)

Iwatake, K., Mizoguchi, T., Tomiyama, S., Zhang, J., Satake, H., Ueda, A., 2013. Geochemical study of groundwater in the Sho river fan, Toyama Pre fecture for heat usage by geothermal heat pump, Geochemical Journal, 47, 577-590.

Japan Meteorological Agency, 2020. Past weather data (Fushiki, Toyama Prefecture). http://www.data. jma.go.jp /obd/stats/etrn/index.php?prec_no=55\&block_no=47606\&year=2012\&month=\&day=\&view=

Kato, S., Mizutani, Y., Uchida, T., lida, C., 1984. Geochemical study of ground water systems in the Shogawa Fan, Toyama, Chikyu-Kagaku, 18, 29-35 (in Japanese with English abstract).

Lei, C., Peng, Z., Day, T., Yan, X., Bai, X., Yuan, C., 2011. Experimental observation of surface morphology effect on crystallization fouling in plate heat exchangers, International Communications in Heat and Mass Transfer, 38, 25-30.

Li, F., Pan, G., Tang, C., Zhang, Q. and Yu, J., 2008. Recharge source and hydrogeochemical evolution of shallow groundwater in a complex alluvial fan system, southwest of North China Plain, Environmental Geology, 55, 1109-1122.

Matsuura, T., Tebakari, T., Oda, A., Ueda, A., 2021. Flow characteristics of artesian groundwater in coastal area of Kurobe River Basin, Toyama Prefecture, by long-term and spatial observation of water temperature and electric conductivity. Groundwater for Sustainable Development, 100555. doi.org/10.1016/j.gsd. 2021.100555

Mizutani, Y., Oda, M., 1983. Stable isotope study of ground water recharge and movement in the Shogawa Fan, Toyama, Chikyu-Kagaku, 17, 1-9 (in Japanese with English abstract).

Mizutani, Y., Satake, H., Takashima, H., 1987. Tritium age of groundwaters from the Shogawa fan, Toyama, Chikyu-Kagaku, 21, 49-54 (in Japanese with English abstract).

Mizutani, Y., Satake, H., Yamabe, A., Miyachi, H., Mase, N., Yamamura, K., 2001. Hydrogen and oxygen isotope ratios of groundwaters in shallow aquifers beneath the alluvial fan, Journal of Groundwater Hydrology, 43, 3-11 (in Japanese with English abstract) 『

Mori, H., Ogawa, Y., Ueda, A., 2020. Geochemical and hydraulic analysis of groundwater for heat utilization around Sakuragaike in Nanto City, Toyama Prefecture, Japan. Environment Earth Science, 79, 483 https://doi.org/10.1007/s12665-020-09231-9

Okakita, N., Iwatake, K., Hirata, A. and Ueda, A., 2019. Contribution of precipitation to groundwater flow systems in three major alluvial fans in Toyama Prefecture, Japan: Stable-isotope characterization and application to the use of groundwater for urban heat exchangers. Hydrologeol. J. 27, 345-362. 
Okano, O., Konishi, A., Kita, A., Ueda, A., 2020. Geochemical study for utilization of groundwater heat by open heat pump system in northern Okayama and Akaiwa city areas with low precipitation in Japan.

Groundwater for Sustainable Development, 100494, https://doi.org/10.1016/j.gsd.2020.100494

Park, Y., Kim, N., Lee, J-Y., 2015. Geochemical properties of groundwater affected by open loop geothermal heat pump systems in Korea. Geosci. J. 19; 515-526.

Pophillat, W., Bayer, P., Teyssier, E., Blum, P., Attard, G., 2020. Impact of groundwater heat pump systems on subsurface temperature under variable advection, conduction and dispersion. Geothermics 83, 101721. https://doi.org/10.1016/j.geothermics.2019.101721.

Pratiwi, A.S., Trutnevyte, E., 2021. Life cycle assessment of shallow to medium-depth geothermal heating and

cooling networks in the State of Geneva. Geothermics, 90, 101988. https://doi.org/10.1016/j.geothermics. 2020.101988

Saito, T., Komatsu, T., 2014. Influence of geothermal heat pump on underground environment. J. Japan Soc. Groundwater 56:15-25. (in Japanese with English abstract)

Sekiya, K., 2003. Vertical distribution of groundwater temperature and its change - Approach to groundwater flow - Niigata J Applied Geol. Res. 61, 19-25. (in Japanese with English abstract)

Takizawa, T., 2011. Underground heat utilization technology 8: Water quality measures for underground heat utilization. J. Japan Soc. Groundwater 53:401-409. (in Japanese with English abstract)

Toyama Prefecture, 2006. "Groundwater guidelines Toyama," edited by Toyama Prefecture, 29p (in Japanese), after http://www.pref.toyama.jp/cms_pfile/00001661/00066924.pdf.

Tsuchihara, T., Yoshimoto, S., Ishida, S., Imaizumi, M., 2011. Classification of Recharge Sources of Groundwater in a Paddy Dominant Alluvial Fan Based on Geochemical and Isotopic Analyses, Bulletin of the National Institute for Rural Engineering, 211, 21-34 (in Japanese with English abstract).

Vanderzalm, J. L., Jeuken, B. M., Wischusen, J. D. H., Pavelic, P., Le Gal La Salle, C., Knapton, A. and Dillon, P. J., 2011. Recharge sources and hydrogeochemical evolution of groundwater in alluvial basins in arid central Australia, Jour. Hydrol., 397, 71-82.

Wang, Y., Wong, K. L., Liu, Q., Jin, Y., Tu, J., 2012. Improvement of energy efficiency for an open-loop surface water source heat pump system via optimal design of water-intake, Energy and Buildings, 51, 93100.

Yamada, Y. and Ueda, A., 2018. Geochemical hydrological analysis of subsurface water system of Sabae Basin, Fukui Prefecture for heat utilization. Chikyukagaku 52, 73-94. (in Japanese with English abstract) 
Yamamoto, T., 1992. Water temperature of groundwater. Groundwater Hydrol. 139-152. (in Japanese with English abstract)

Yuan, R., Song, X., Zhang, Y., Han, D., Wang, S. and Tang, C., 2011. Using major ions and stable isotopes to characterize recharge regime of a fault-influenced aquifer in Beiyishui River Watershed, North China Plain, Jour. Hydrol., 405, 512-521.

\section{Tables}

Due to technical limitations, the tables are only available as a download in the supplemental files section.

\section{Figures}




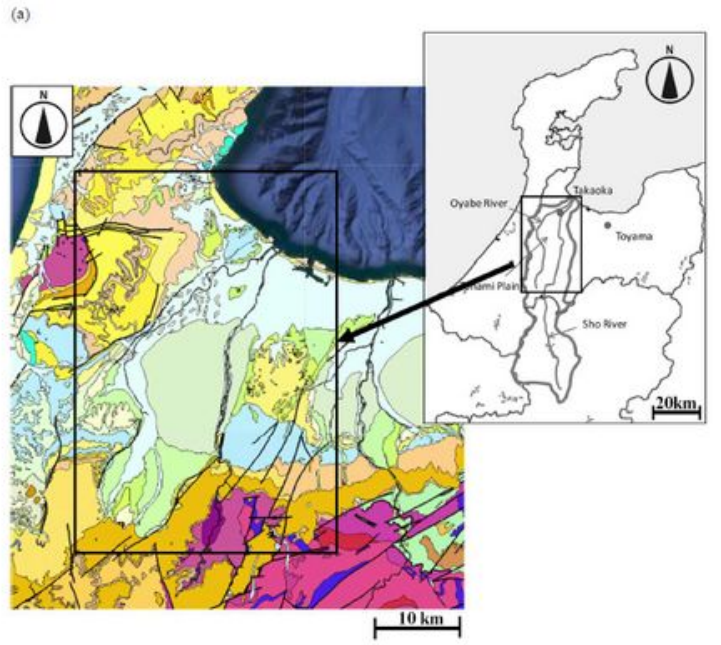

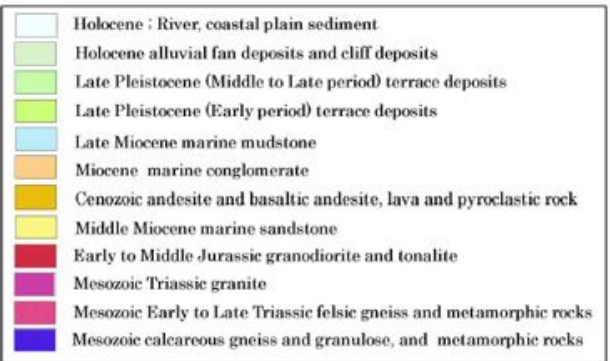

(b)

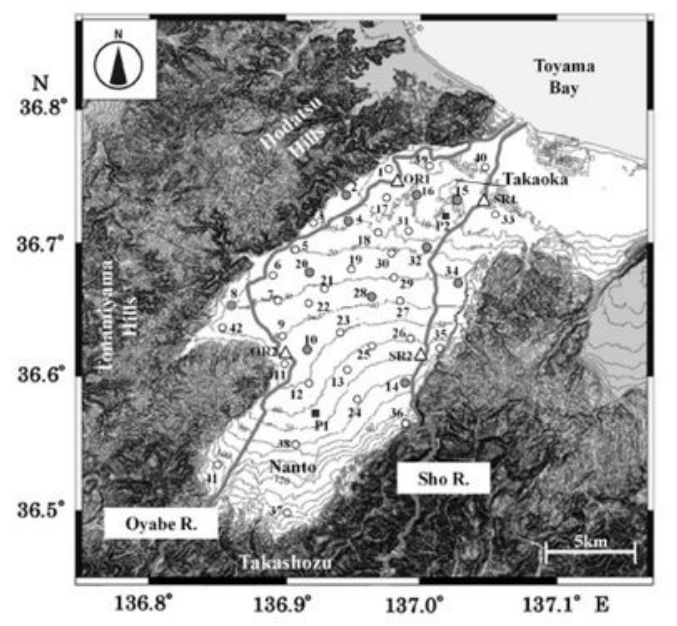

- Groundwater collected monthly

Groundwater collected every two months

$\triangle$ Rive water

$\square \quad$ Precipitation

\section{Figure 1}

(a) Geological map of the study area (AIST, 2015) and (b) location of water samples in Sho River alluvial fan. The contour intervals are $10 \mathrm{~m}$. Note: The designations employed and the presentation of the material on this map do not imply the expression of any opinion whatsoever on the part of Research Square concerning the legal status of any country, territory, city or area or of its authorities, or concerning the delimitation of its frontiers or boundaries. This map has been provided by the authors. 


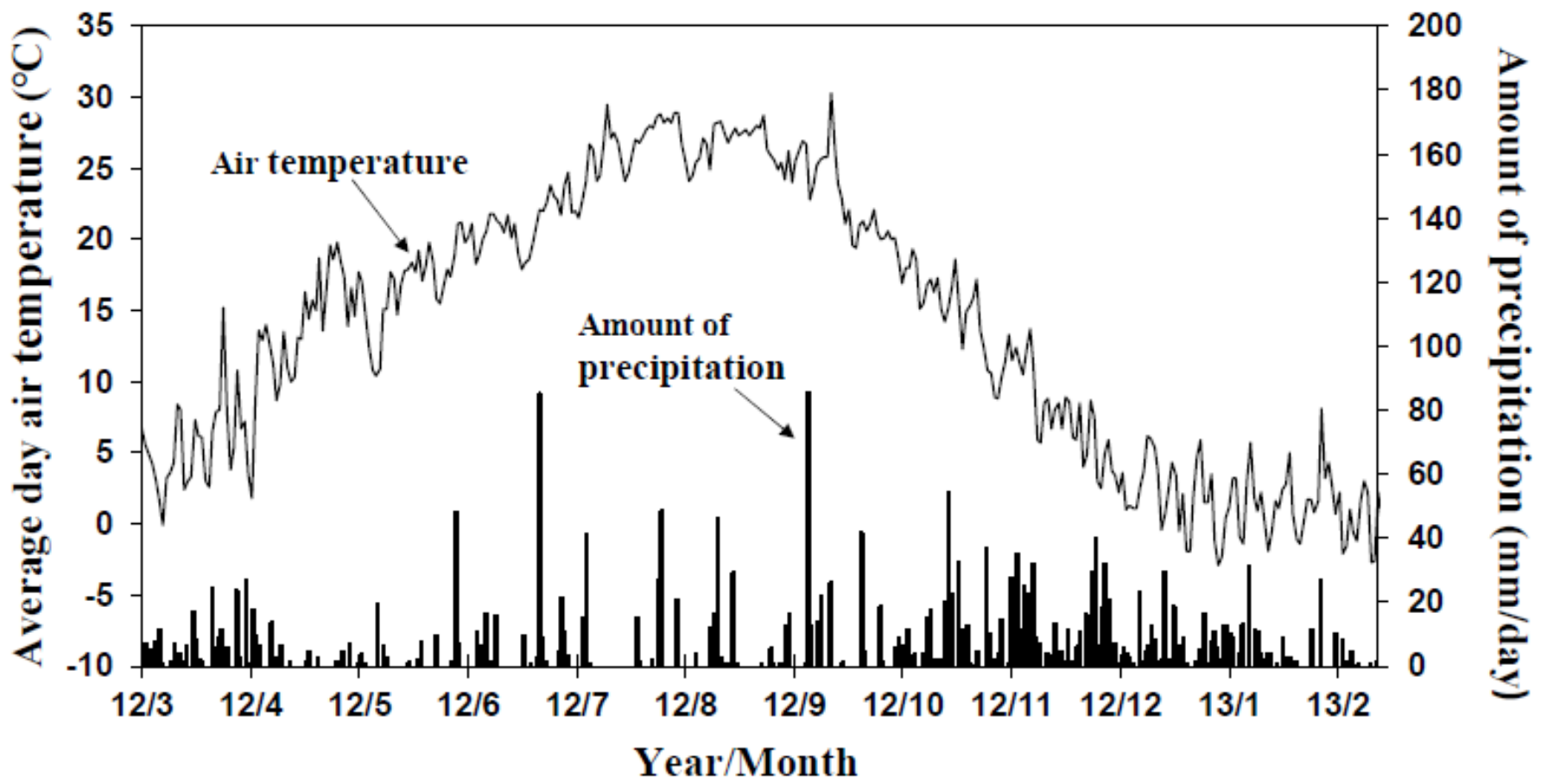

Figure 2

Average daily air temperature and precipitation at Takaoka City (Japan Meteorological Agency, 2020). 
(a)

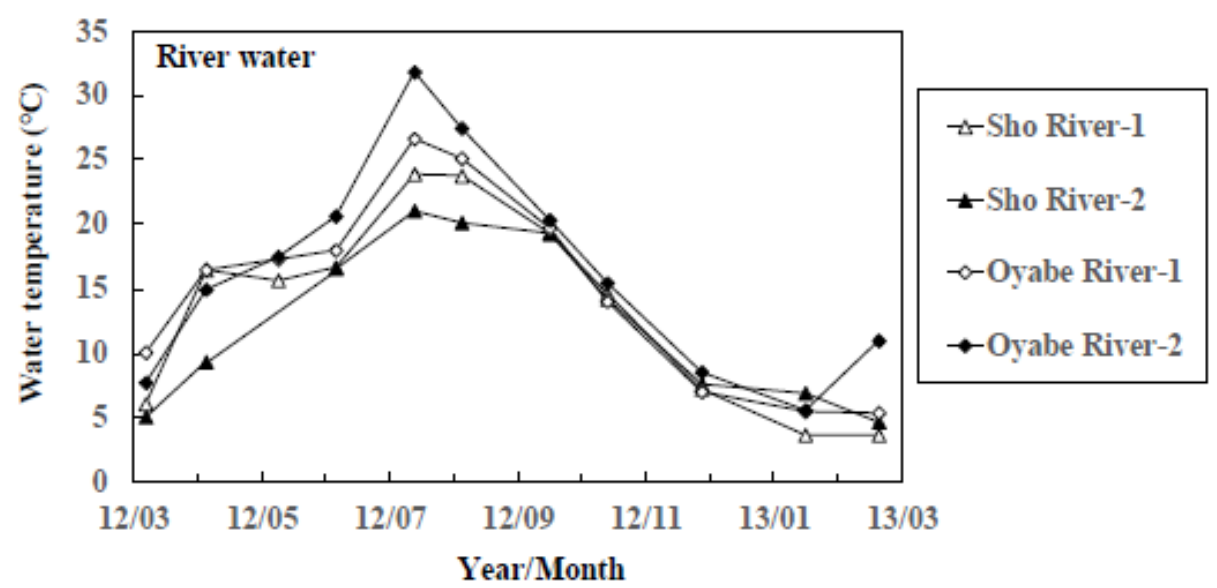

(b)

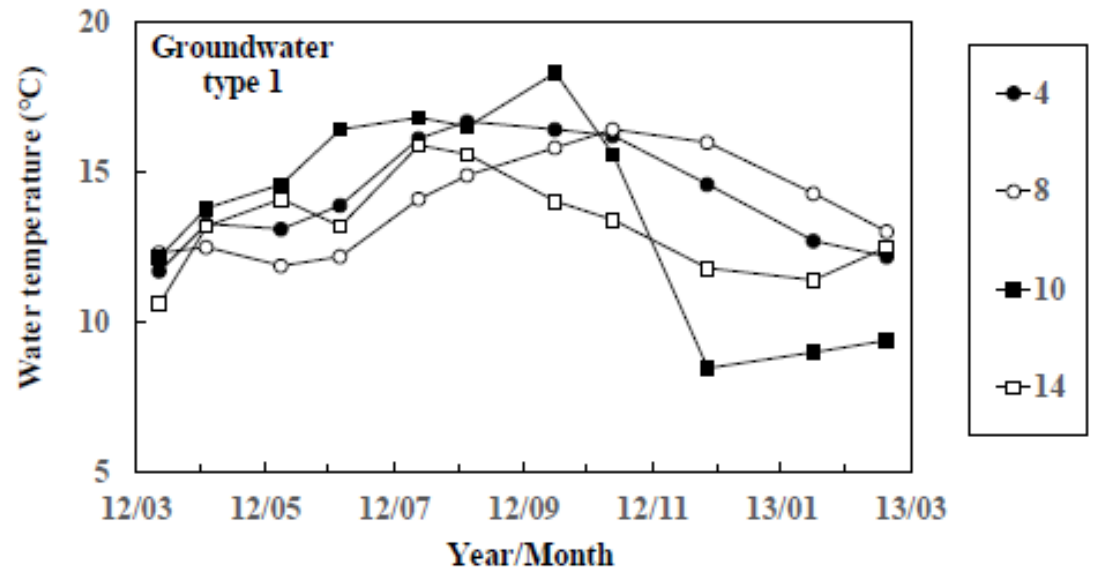

(c)

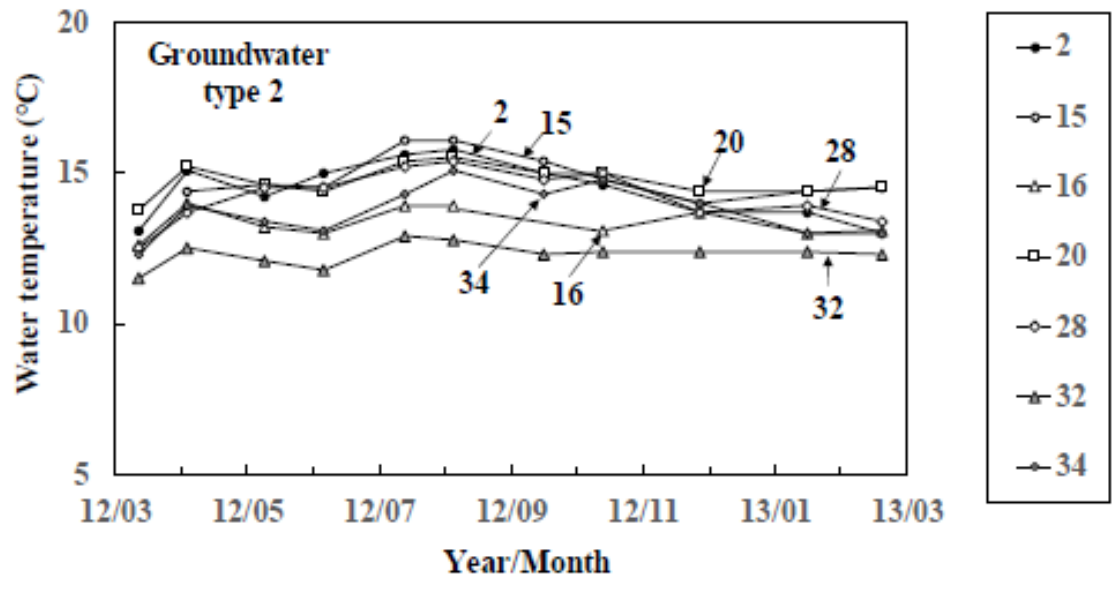

Figure 3

Seasonal variation of water temperature of river water and groundwater (Types 1 and 2) at 11 representative sites. 


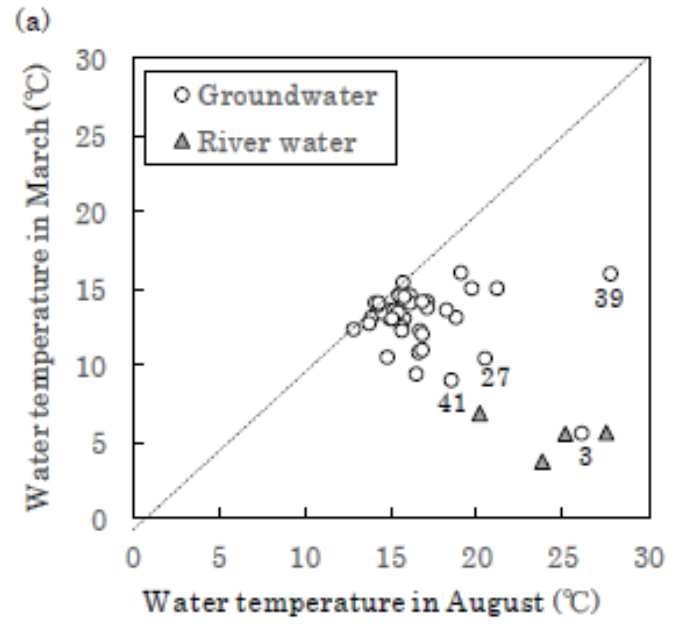

(b)

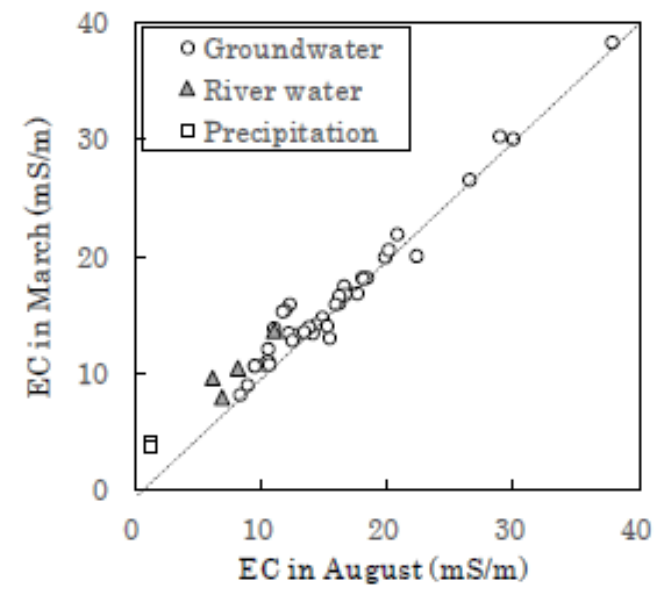

(c)

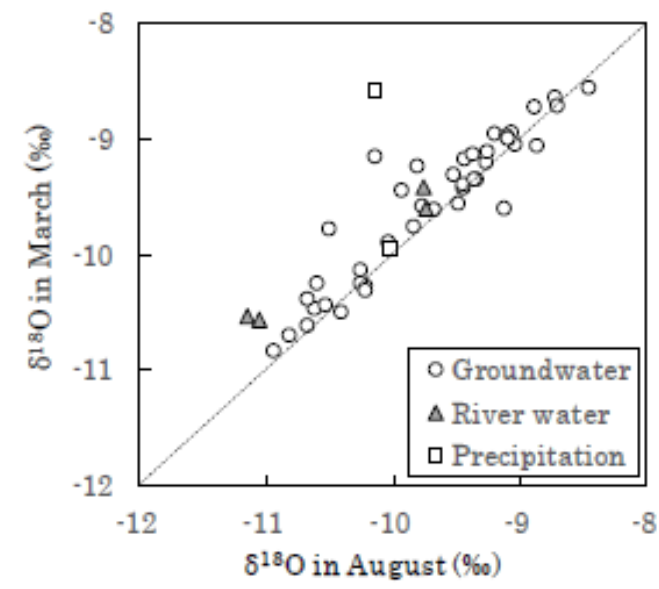

Figure 4

(a) Temperature, (b) EC, and (c) $\delta 180$ difference for groundwater and river water between August and March. The broken lines indicate constant values throughout a year at each sampling site. 
(a)

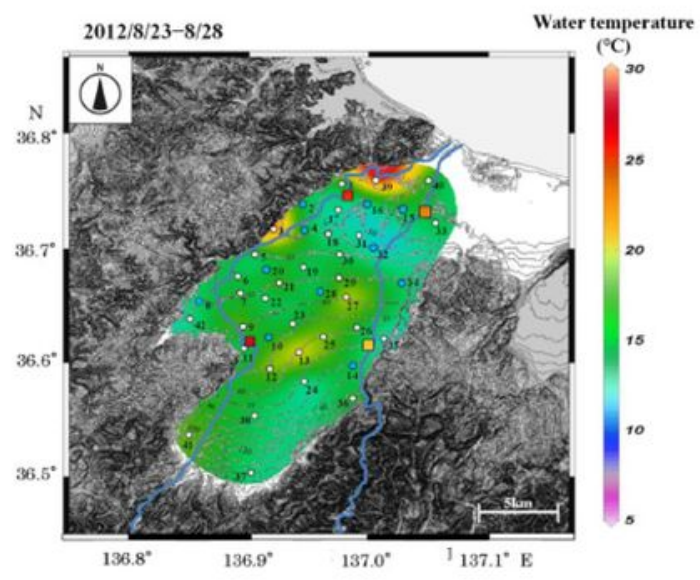

(b)

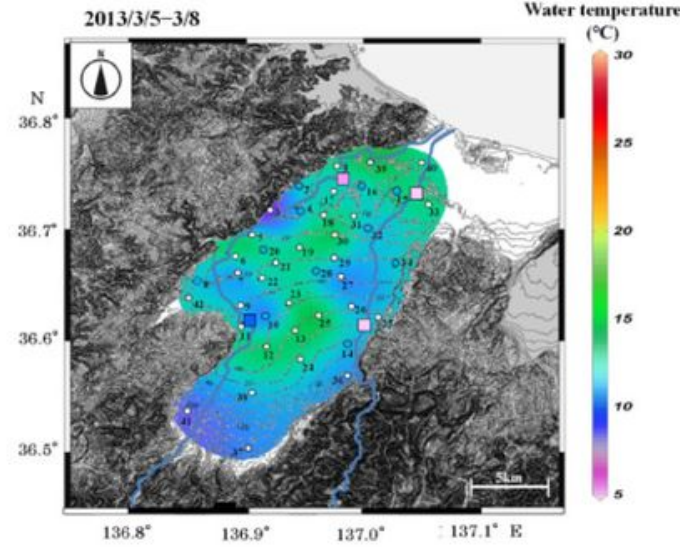

(c)

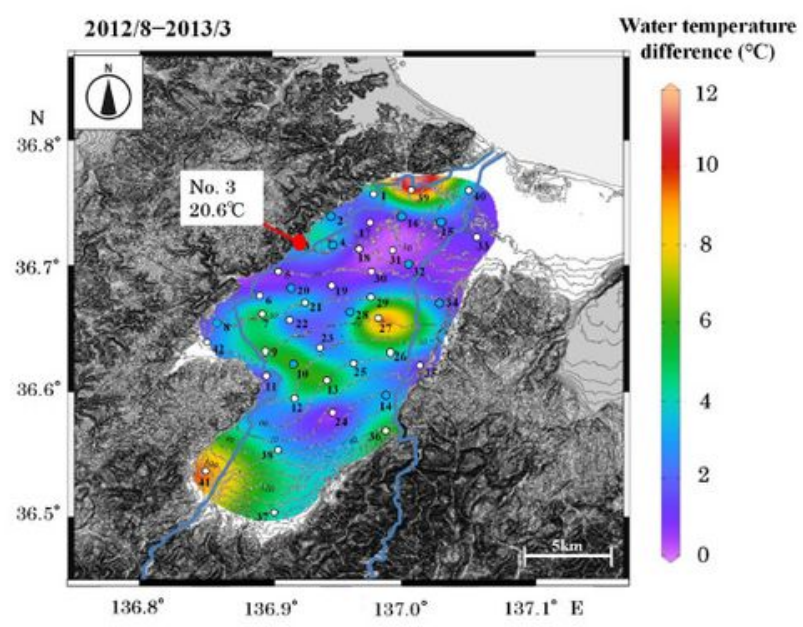

Figure 5

Contour map of groundwater temperature in (a) 2012/8/23-8/28 and (b) $2013 / 3 / 5-3 / 8$. (c) Water temperature differences between 2012/8 and 2013/3. Temperatures of river water are shown by color of the squares. Note: The designations employed and the presentation of the material on this map do not imply the expression of any opinion whatsoever on the part of Research Square concerning the legal 
status of any country, territory, city or area or of its authorities, or concerning the delimitation of its frontiers or boundaries. This map has been provided by the authors.

(a)

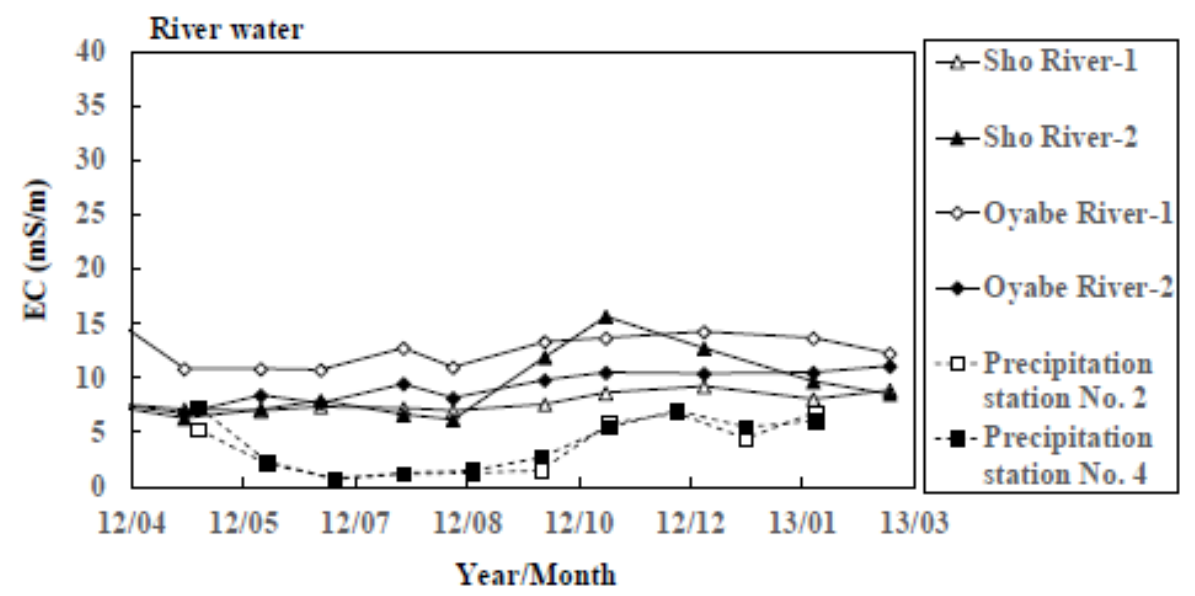

(b)

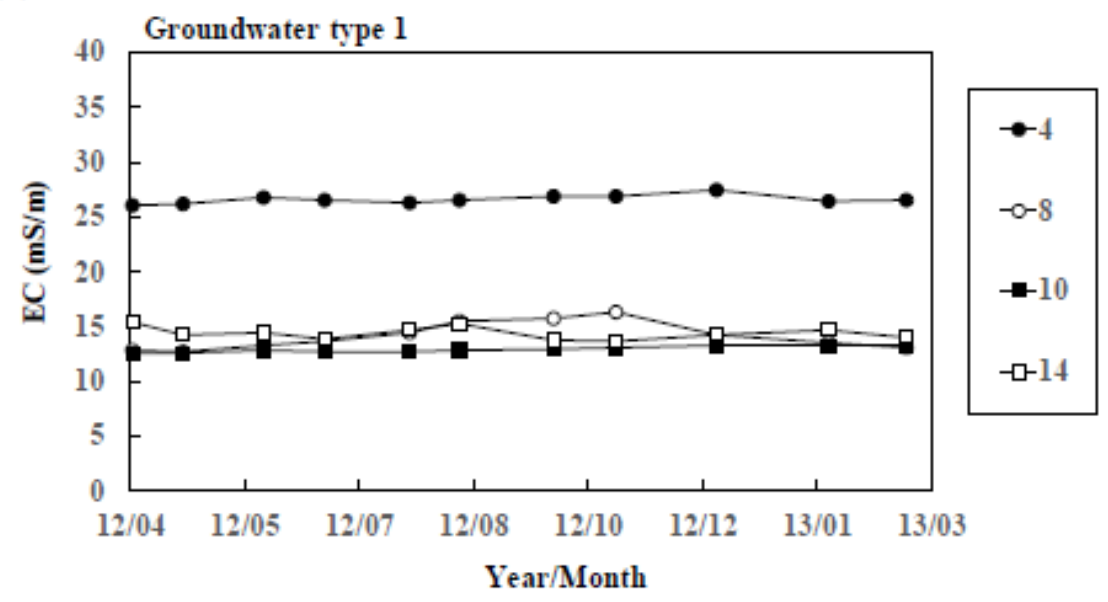

(c)

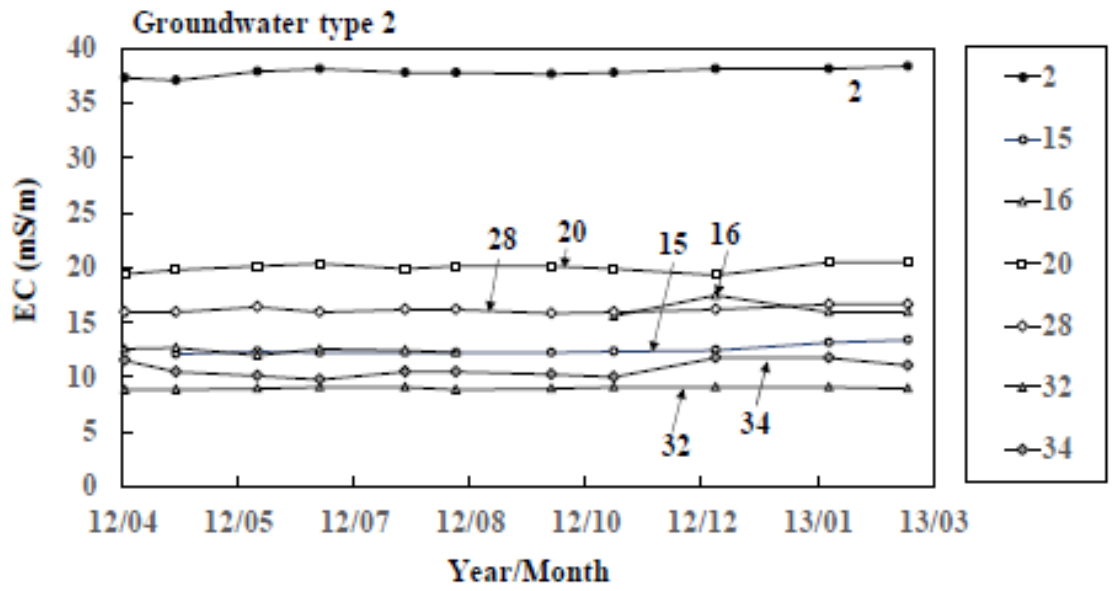

Figure 6

Seasonal variation of electric conductivity in river water and groundwater (Types 1 and 2) at 11 representative sites. 
(a)

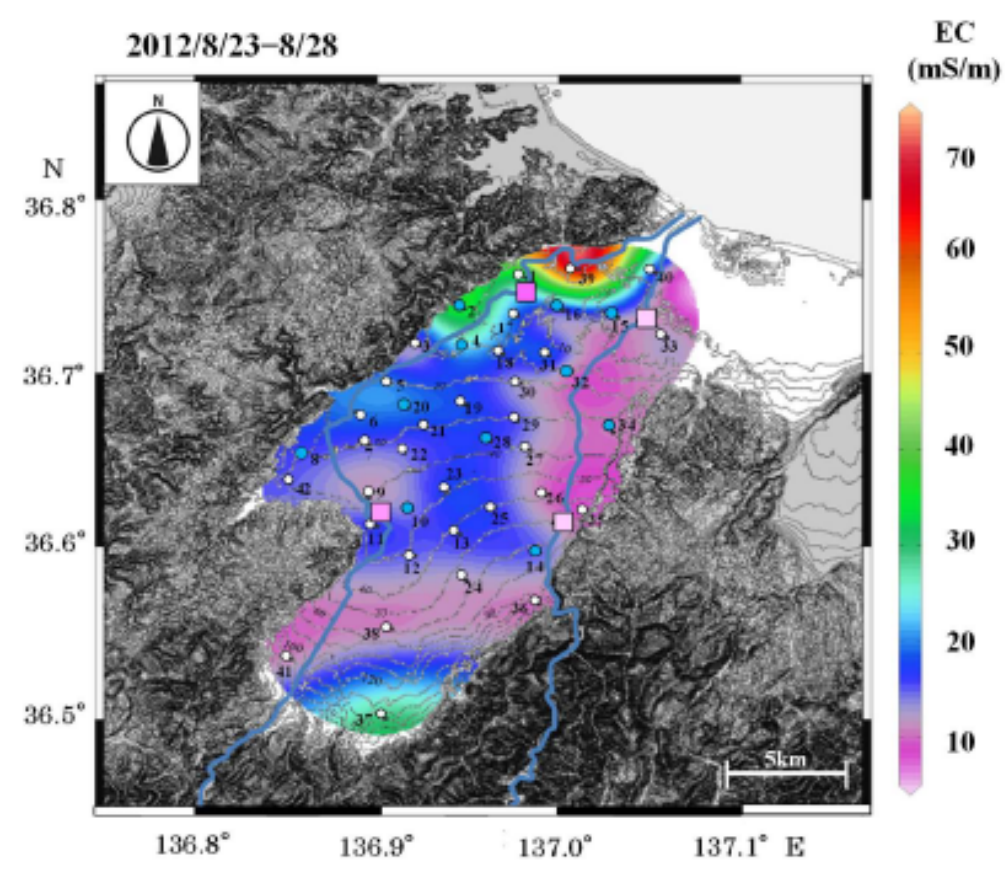

(b)

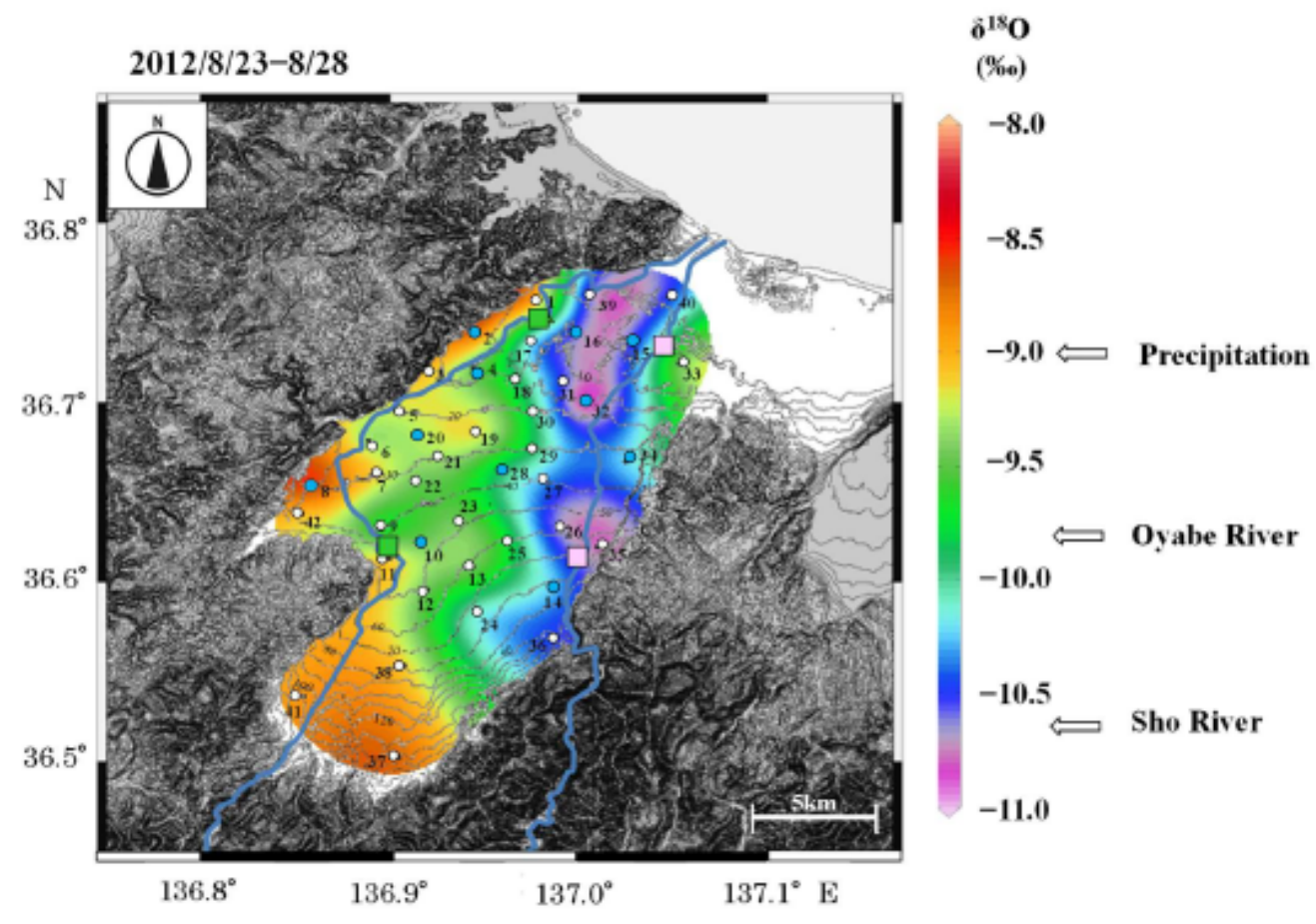

\section{Figure 7}

Contour maps of EC and $\delta 180$ for groundwater samples in August 2012. Note: The designations employed and the presentation of the material on this map do not imply the expression of any opinion whatsoever on the part of Research Square concerning the legal status of any country, territory, city or area or of its authorities, or concerning the delimitation of its frontiers or boundaries. This map has been provided by the authors. 
(a)

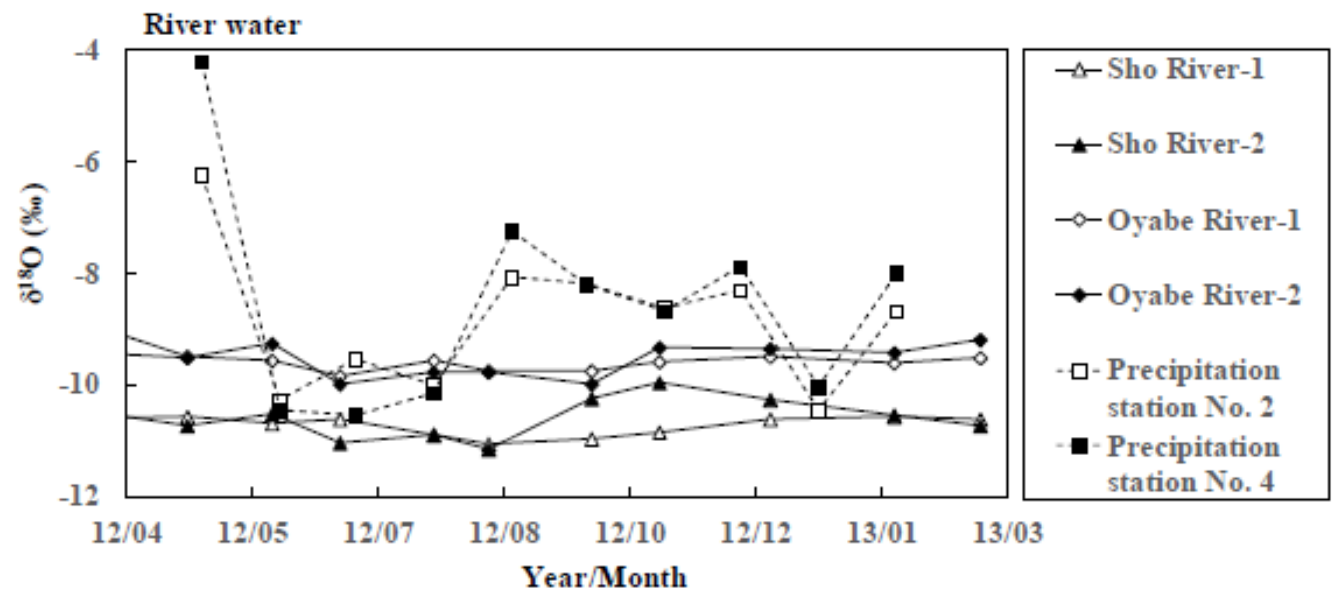

(b)

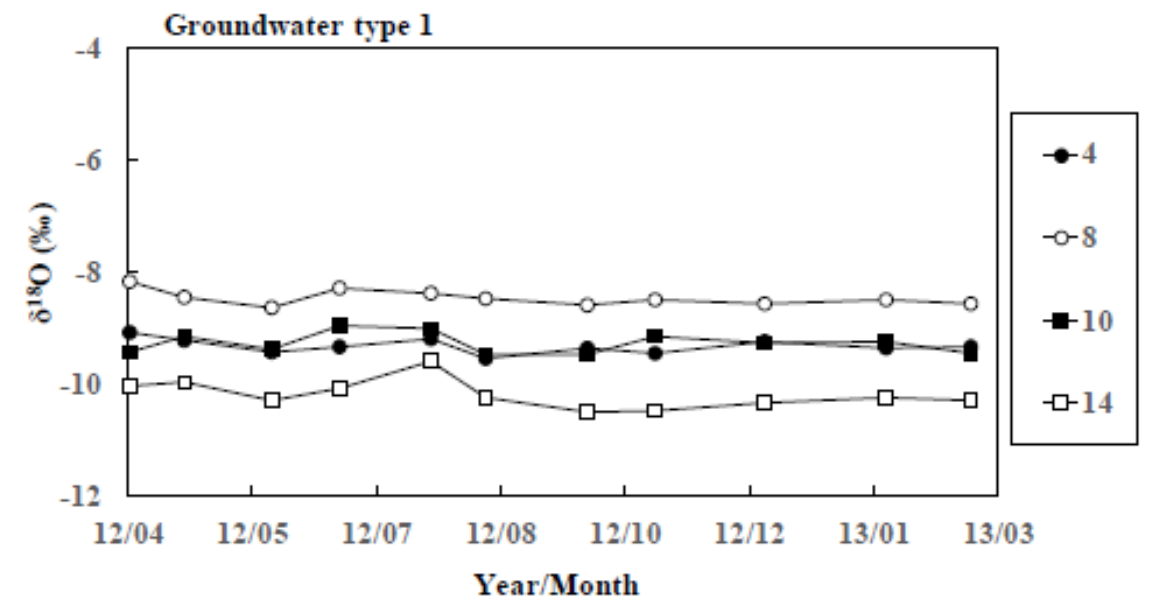

(c)

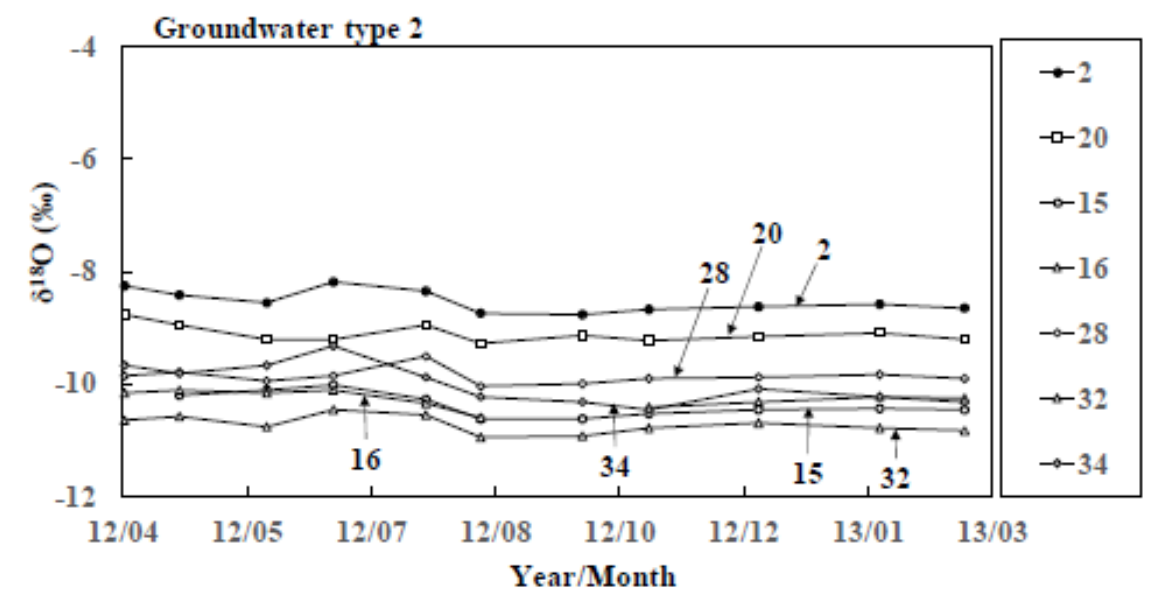

Figure 8

Seasonal variations of $\delta 180$ values for river water and groundwater (Types 1 and 2 ) at 11 representative sites. 
(a)
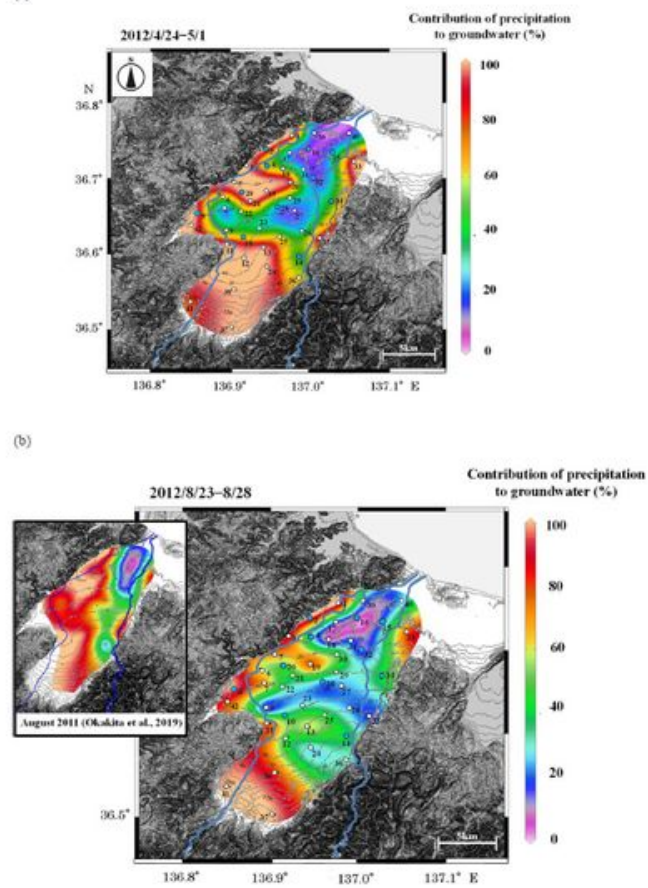

(c)
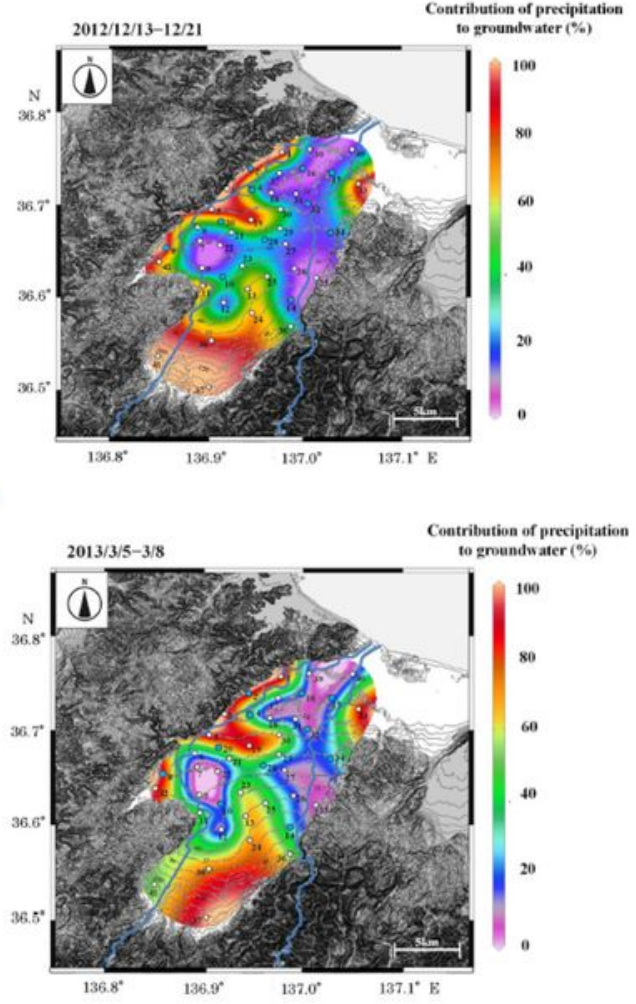

Figure 9

Contour maps of contribution of precipitation to groundwater in (a) 2012/4/24-5/1, (b) 2012/8/23-8/28, (c) 2012/12/13-12/21, and (d) 2013/3/5-5/8. In Fig. 9b, a contour map in August 2011 is also shown, which was modified from Okakita et al. (2019). Note: The designations employed and the presentation of the material on this map do not imply the expression of any opinion whatsoever on the part of Research 
Square concerning the legal status of any country, territory, city or area or of its authorities, or concerning the delimitation of its frontiers or boundaries. This map has been provided by the authors.

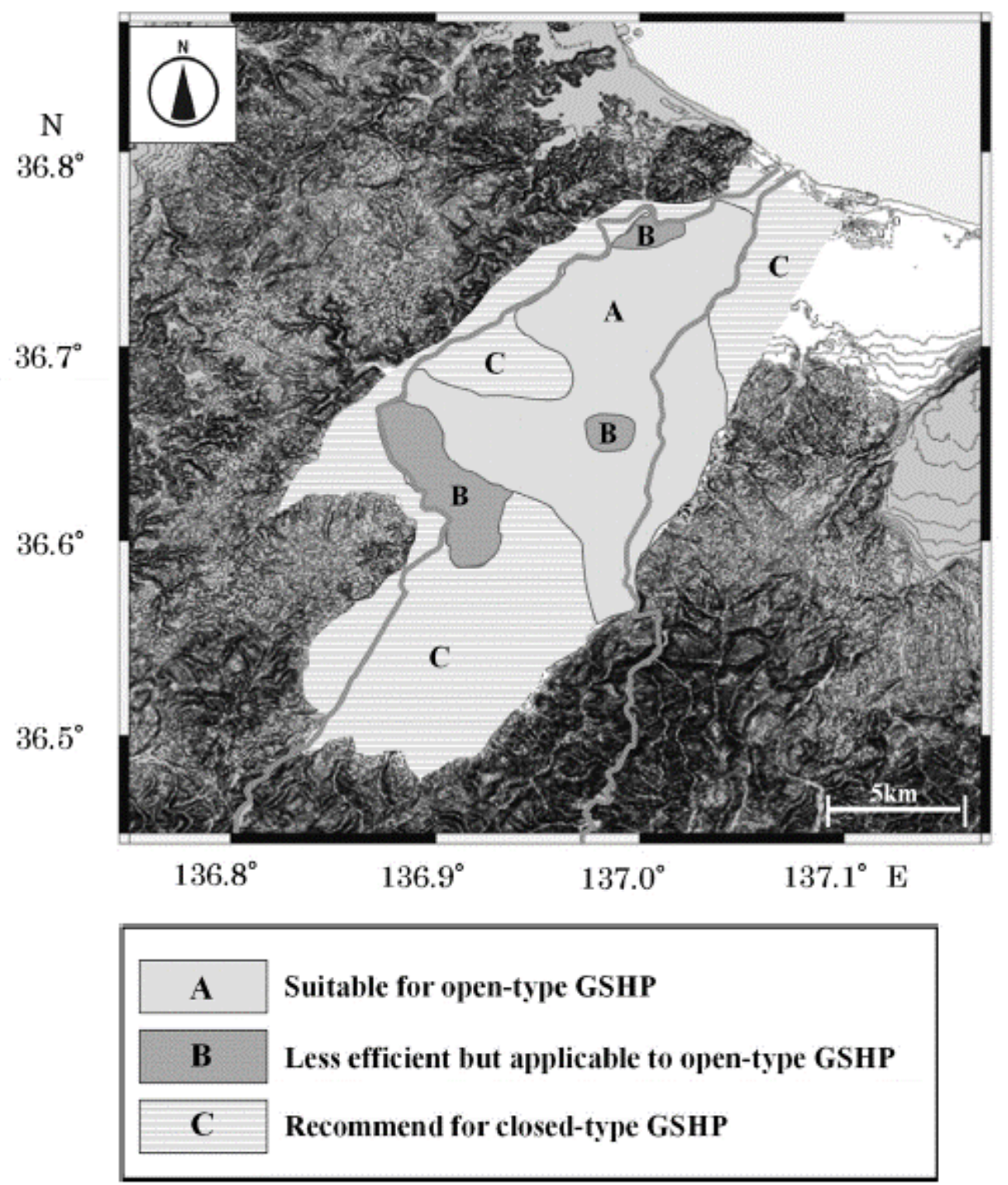

Figure 10

A map showing the study area where open-type ground source heat-pump systems (GSHPs) are recommended. Note: The designations employed and the presentation of the material on this map do not imply the expression of any opinion whatsoever on the part of Research Square concerning the legal status of any country, territory, city or area or of its authorities, or concerning the delimitation of its frontiers or boundaries. This map has been provided by the authors.

\section{Supplementary Files}

This is a list of supplementary files associated with this preprint. Click to download. 
- Iwatake1Tables0307.pdf

Page 23/23 